\title{
ВПЛИВ ПОПЕРЕДНИКІВ ТА МІНЕРАЛЬНОГО ЖИВЛЕННЯ НА УРОЖАЙНІСТЬ І ЯКІСТЬ ЗЕРНА ПШЕНИЦІ ОЗИМОЇ
}

\author{
Н. М. Усова ${ }^{1}$, М. М. Солодуико ${ }^{2}$, О. Л. Романенко ${ }^{3}$ \\ ${ }^{1}$ Інститут олійних культур НААН, вул. Інститутська, 1, смт. Сонячне, Запорізький район, Запо- \\ різька область, 70417, Україна \\ ${ }^{2}$ Державна установа Інститут зернових культур НААН, вул. Володимира Вернадського, 14, \\ м. Дніпро, 49027, Україна \\ ${ }^{3}$ Запорізька філія Державної установи «Інститут охорони грунтів України», вул. Дослідна станція, \\ 94, м. Запоріжжя, 69031, Україна
}

Наведено результати дослідження впливу попередників та мінерального живлення на врожайність різних сортів пшенииі озимої в умовах південного Степу Украӥни. Визначено кращі попередники та встановлено оптимальні системи мінерального живлення, які забезпечують високі показники урожайності та якості зернової продукиії.

На основі результатів дослідження встановлено, що високу врожсайність сорти Антонівка $(5,77 \mathrm{~m} / 2 \mathrm{a})$ та Гурт $(5,67 \mathrm{~m} / 2 a)$ сформували по чорному пару на фоні передпосівного внесення $N_{40} P_{40} K_{40}$ з наступним піджсиленням посівів азотом $\left(N_{90}\right)$ ранньою весною по мерзлоталому грунту. В иілому сорти пшениці озимої залежно від попередників реагували в напрямку від краших до гірших - зменшенням урожайності. В умовах 2015-2017 рр. кращим непаровим попередником серед досліджуваних для пшениці озимої була гірчиия, гіршим - пшениия озима.

Встановлено, що за рахунок азотного підживлення посівів озимини, вміст білка і клейковини в зерні збільшувався.

Ключові слова: пшениия озима, урожайність, попередники, мінеральні добрива, якість зерна, білок, клейковина, маса 1000 зерен.

Пшениця озима (Triticum aestivum L.) в Степу України є основною зерновою культурою. На відміну від інших сільськогосподарських культур вона має велике агротехнічне та економічне значення для агропромислової сфери [1-3].

Серед факторів, які впливають на урожайність пшениці озимої, чільне місце посідають попередники. Як зазначав В. Н. Ремесло, залежність сортів від попередників настільки велика, що вони навіть перевищують вплив інших елементів агротехніки [4].

Від попередників істотно залежить якість зерна пшениці озимої. Різні культури сівозміни впродовж вегетації по-різному використовують вологу і поживні речовини 3 грунту і неоднаково збагачують його органічними та мінеральними речовинами за ра- хунок пожнивних решток, у різний час звільняють поле для обробітку грунту [5].

У зв'язку з тим, що в умовах нашої держави простежується тенденція до постійного зменшення посівних площ під чорним та зайнятим паром, бобовими культурами і багаторічними травами, особливої уваги заслуговує підбір добрих попередників для пшениці озимої як важливого резерву підвищення іiі урожайності [6].

Одним із важливих факторів регулювання живлення рослин пшениці озимої, а отже, підвищення урожайності і поліпшення якості зерна $є$ удобрення. Тільки забезпечивши рослину достатньою кількістю поживних речовин впродовж вегетації можна одержати вагомий урожай 3 добрими технологічними властивостями зерна. Тому при розробленні

\footnotetext{
Інформація про авторів:

Усова Надія Миколаївна, наук. співробітник, завідувач лаб. агротехніки зернових культур, e-mail: usova28@i.ua, http://orcid.org/0000-0002-7241-7601

Романенко Олександр Леонідович, канд. с.-г. наук, стариий наук. співробітник, заступник директора, e-mail: zpgrunt@ukr.net, http://orcid.org/0000-0002-7619-3502

Солодушко Микола Миколайович, канд. с.-г. наук, старший наук. співробітник, завідувач лаб. агробіологічних ресурсів озимих зернових культур, e-mail: solodushko.nv@gmail.com, http://orcid.org/0000-0002-6329-5227
} 
технології вирощування польових культур особливу увагу треба приділяти системі їх удобрення.

Поживна цінність пшениці озимої та якість хліба в кінцевому підсумку залежать від вмісту клейковини і білка в зерні, основним структурним елементом яких $є$ азот, тому для формування високоякісного зерна рослинам потрібний насамперед цей елемент живлення [7].

Залежно від якісних показників зерно пшениці м'якої в Україні згідно 3 діючим національним стандартом (ДСТУ 3768:2010) ділять на шість класів: перший - третій - група $\mathrm{A}$; четвертий - п'ятий - група $\mathrm{B}$ і шостий. Пшеницю м'яку групи А використовують для продовольчих (переважно в борошномельній і хлібопекарській галузях) цілей та на експорт, пшеницю групи В і шостого класу - на продовольчі та непродовольчі потреби й експорт.

Масова частка білка у перерахунку на суху речовину в зерні першого класу якості повинна становити не менше $14 \%$, сирої клейковини - $28 \%$, другого - відповідно 12,5 і $23 \%$; третього - 11,0 і 18,0\%. Число ВДК для першого і другого класів має коливатись у межах 45-100, третього - 20-100 одиниць приладу. Для четвертого та п'ятого класів масова частка білка повинна становити не менше 12,5 та $10,5 \%$, масову частку клейковини i iii якість (ВДК) для цих класів не обмежують. Для шостого класу вищенаведені показники якості не нормуються [8].

Матеріали і методика дослідження. Польові досліди проводили в 2015-2017 pр. у сівозміні лабораторії агротехніки зернових культур Інституту олійних культур НААН. Грунт дослідної ділянки - чорнозем звичайний середньопотужний малогумусний з вмістом гумусу в орному шарі (до 30 см) 3,5 \%, доступного азоту - 7,2-8,5, рухомого фосфору - 9,6-10,3, обмінного калію - 15,216,9 мг/100 г абсолютно сухого грунту, $\mathrm{pH}$ грунтового розчину $6,5-7,0$. Технологія вирощування пшениці озимої - загальноприйнята для південної частини Степу України, крім поставлених на вивчення питань.

Висівали такі сорти пшениці м'якої озимої, як Антонівка і Гурт. Сівбу проводили 25 вересня селекційною сівалкою СКС-6-10, норма висіву 4,5 млн схожих насінин/га. Глибина загортання насіння $-5-6$ см. Спосіб сівби - суцільний рядковий. Попередники чорний пар, гірчиця, соняшник, пшениця озима. Повторність - чотириразова, розмір залікової ділянки $24 \mathrm{~m}^{2}(16$ х 1,5 м). Мінеральні добрива вносили відповідно до схеми

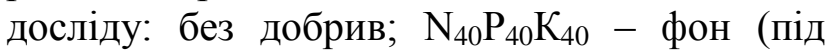
передпосівну культивацію); фон $+\mathrm{N}_{30}$ по мерзлоталому грунту; фон $+\mathrm{N}_{60}$ по мерзлоталому грунту; фон $+\mathrm{N}_{90}$ по мерзлоталому грунту. Заходи захисту рослин - 3 урахуванням економічного порогу шкодочинності. В дослідженнях керувалися методикою дослідної справи Б. О. Доспєхова та методичними порадами Всесоюзного науково-дослідного інституту кукурудзи для проведення польових дослідів із зерновими, зернобобовими і кормовими культурами $[9,10]$.

Результати дослідження. На підставі одержаних даних встановлено, що найбільшу урожайність сорти Антонівка (5,77 т/га) i Гурт $(5,67$ т/га) сформували на ділянках по чорному пару на фоні предпосівного внесення $\mathrm{N}_{40} \mathrm{P}_{40} \mathrm{~K}_{40} 3$ подальшим підживленням посівів азотом $\left(\mathrm{N}_{90}\right)$ ранньою весною по мерзлоталому грунту (табл. 1).

В цілому сорти пшениці озимої на зміну попередників реагували в напрямку від кращих до гірших - зменшенням урожайності.

Так, по чорному пару у варіанті без добрив урожайність сорту Антонівка становила 4,74 т/га, в той час як після гірчиці в аналогічних умовах вона знижувалась на 0,88 т/га $(18,6 \%)$, соняшника - на 2,29 т/га (48,3\%), пшениці озимої - на 2,67 т/га (56,3 \%). Зниження урожайності сорту Гурт при вирощуванні після перелічених непарових попередників порівняно 3 чорним паром становило відповідно 17,8, 49,0 та 58,2 \%. Така ж тенденція мала місце й в інших варіантах досліду. Тобто урожайність пшениці озимої суттєво змінювалась залежно від попередника.

Слід відзначити, що для умов південного Степу України, найбільш надійним попередником для озимини є чорний пар. В 2015-2017 рр. кращим непаровим попередником (серед досліджуваних) для неї була гірчиця, найгіршим - пшениця озима.

Результати обліку урожаю пшениці озимої при вирощуванні на фоні внесення різних 


\section{1. Урожайність сортів пиениці озимої залежно від попередників та мінерального живлення (середнс за 2015-2017 рр.)}

\begin{tabular}{|c|c|c|c|c|c|c|c|c|c|c|}
\hline \multirow{4}{*}{$\begin{array}{c}\text { Система } \\
\text { мінерального } \\
\text { живлення }\end{array}$} & \multicolumn{10}{|c|}{ Попередники } \\
\hline & \multirow{3}{*}{$\begin{array}{c}\text { чорний } \\
\text { пар }\end{array}$} & \multicolumn{3}{|c|}{ гірчиця } & \multicolumn{3}{|c|}{ соняшник } & \multicolumn{3}{|c|}{ пшениця озима } \\
\hline & & \multirow[t]{2}{*}{ т/га } & \multicolumn{2}{|c|}{$\begin{array}{c}\text { приріст } \\
\text { до } \\
\text { контролю }\end{array}$} & \multirow[t]{2}{*}{ т/га } & \multicolumn{2}{|c|}{$\begin{array}{c}\text { приріст } \\
\text { до } \\
\text { контролю }\end{array}$} & \multirow[t]{2}{*}{ т/га } & \multicolumn{2}{|c|}{$\begin{array}{c}\text { приріст } \\
\text { до } \\
\text { контролю }\end{array}$} \\
\hline & & & т/га & $\%$ & & т/га & $\%$ & & т/га & $\%$ \\
\hline \multicolumn{11}{|c|}{ Антонівка } \\
\hline Без добрив (контроль) & 4,74 & 3,86 & 0,88 & 18,6 & 2,45 & 2,29 & 48,3 & 2,07 & 2,67 & 56,3 \\
\hline $\mathrm{N}_{40} \mathrm{P}_{40} \mathrm{~K}_{40}-$ фон & 5,15 & 4,31 & 0,84 & 16,3 & 2,82 & 2,33 & 45,2 & 2,39 & 2,76 & 53,6 \\
\hline$\Phi$ он $+\mathrm{N}_{30}$ по МТГ $*$ & 5,46 & 4,55 & 0,91 & 16,7 & 3,17 & 2,29 & 41,9 & 2,71 & 2,75 & 50,4 \\
\hline Фон $+\mathrm{N}_{60}$ по МТГ & 5,63 & 4,84 & 0,79 & 14,0 & 3,37 & 2,26 & 40,1 & 2,87 & 2,76 & 49,0 \\
\hline Фон $+\mathrm{N}_{90}$ по МТГ & 5,77 & 5,08 & 0,69 & 11,9 & 3,52 & 2,25 & 39,0 & 3,06 & 2,71 & 47,0 \\
\hline \multicolumn{11}{|c|}{ Гурт } \\
\hline Без добрив (контроль) & 4,71 & 3,87 & 0,84 & 17,8 & 2,40 & 2,31 & 49,0 & 1,97 & 2,74 & 58,2 \\
\hline $\mathrm{N}_{40} \mathrm{P}_{40} \mathrm{~K}_{40}-$ фон & 5,09 & 4,26 & 0,83 & 16,3 & 2,88 & 2,21 & 43,4 & 2,35 & 2,74 & 53,8 \\
\hline Фон + $\mathrm{N}_{30}$ по МТГ & 5,38 & 4,53 & 0,85 & 15,8 & 3,22 & 2,16 & 40,1 & 2,76 & 2,62 & 48,7 \\
\hline Фон $+\mathrm{N}_{60}$ по МТГ & 5,54 & 4,80 & 0,74 & 13,4 & 3,42 & 2,12 & 38,3 & 2,98 & 2,56 & 46,2 \\
\hline Фон $+\mathrm{N}_{90}$ по МТГ & 5,67 & 5,02 & 0,65 & 11,5 & 3,57 & 2,10 & 37,0 & 3,20 & 2,47 & 43,6 \\
\hline
\end{tabular}

* Мерзлоталий трунт.

2. Якість зерна сортів пшениці озимої Антонівка і Гурт залежно від попередників та мінерального живлення (середнс за 2015-2017 рр.)

\begin{tabular}{|c|c|c|c|c|c|c|c|c|}
\hline \multirow{4}{*}{$\begin{array}{c}\text { Система } \\
\text { мінерального } \\
\text { живлення }\end{array}$} & \multicolumn{8}{|c|}{ Сорти } \\
\hline & \multicolumn{4}{|c|}{ Антонівка } & \multicolumn{4}{|c|}{ Гурт } \\
\hline & \multicolumn{2}{|c|}{ вміст у зерні, \% } & \multirow{2}{*}{$\begin{array}{c}\text { ВДК, } \\
\text { од. } \\
\text { прила- } \\
\text { ду }\end{array}$} & \multirow{2}{*}{$\begin{array}{c}\text { маса } \\
1000 \\
\text { зерен, } \\
\Gamma\end{array}$} & \multicolumn{2}{|c|}{ вміст у зерні, \% } & \multirow{2}{*}{$\begin{array}{c}\text { ВДК, } \\
\text { од. } \\
\text { прила- } \\
\text { ду }\end{array}$} & \multirow{2}{*}{$\begin{array}{c}\text { маса } \\
1000 \\
\text { зерен, } \\
\Gamma\end{array}$} \\
\hline & білка & $\begin{array}{c}\text { клейко- } \\
\text { вини }\end{array}$ & & & білка & $\begin{array}{c}\text { клей- } \\
\text { ковини }\end{array}$ & & \\
\hline \multicolumn{9}{|c|}{ Попередник - чорний пар } \\
\hline Без добрив (контроль) & 9,0 & 19,6 & 74 & 37,1 & 9,2 & 19,2 & 74 & 37,9 \\
\hline $\mathrm{N}_{40} \mathrm{P}_{40} \mathrm{~K}_{40}-$ фон & 9,9 & 22,5 & 79 & 39,2 & 10,3 & 22,0 & 74 & 39,4 \\
\hline Фон $+\mathrm{N}_{30}$ по МТГ & 11,1 & 23,4 & 79 & 41,3 & 11,5 & 24,1 & 75 & 40,7 \\
\hline$\Phi$ он $+\mathrm{N}_{60}$ По МТГ & 11,3 & 27,5 & 77 & 42,4 & 11,8 & 25,0 & 79 & 43,0 \\
\hline Фон $+\mathrm{N}_{90}$ по МТГ & 12,0 & 28,9 & 76 & 43,3 & 12,0 & 25,9 & 80 & 43,6 \\
\hline \multicolumn{9}{|c|}{ Попередник - гірчиця } \\
\hline Без добрив (контроль) & 7,7 & 15,3 & 69 & 36,2 & 8,1 & 16,6 & 67 & 37,7 \\
\hline $\mathrm{N}_{40} \mathrm{P}_{40} \mathrm{~K}_{40}-$ фон & 8,8 & 15,4 & 67 & 39,1 & 9,2 & 17,8 & 70 & 39,7 \\
\hline$\Phi$ он $+\mathrm{N}_{30}$ по МТГ & 9,9 & 17,0 & 74 & 39,8 & 9,6 & 18,8 & 76 & 41,7 \\
\hline$\Phi$ он $+\mathrm{N}_{60}$ по МТГ & 11,3 & 21,5 & 77 & 41,4 & 11,3 & 22,3 & 82 & 42,6 \\
\hline Фон $+\mathrm{N}_{90}$ по МТГ & 11,8 & 23,7 & 75 & 42,6 & 11,6 & 22,7 & 80 & 43,9 \\
\hline \multicolumn{9}{|c|}{ Попередник - соняшник } \\
\hline Без добрив (контроль) & 6,6 & 13,3 & 65 & 37,6 & 8,2 & 14,9 & 70 & 37,3 \\
\hline $\mathrm{N}_{40} \mathrm{P}_{40} \mathrm{~K}_{40}-$ фон & 8,0 & 14,7 & 65 & 38,6 & 8,4 & 15,7 & 72 & 39,4 \\
\hline Фон $+\mathrm{N}_{30}$ по МТГ & 9,1 & 17,4 & 75 & 39,9 & 10,0 & 18,1 & 76 & 40,7 \\
\hline Фон + N60 по МТГ & 11,2 & 22,8 & 81 & 40,5 & 11,1 & 21,4 & 78 & 40,9 \\
\hline$\Phi$ Фо $+\mathrm{N}_{90}$ по МТГ & 11,5 & 24,4 & 81 & 41,1 & 11,4 & 23,0 & 77 & 41,6 \\
\hline \multicolumn{9}{|c|}{ Попередник - пшениця озима } \\
\hline Без добрив (контроль) & 6,7 & 14,0 & 72 & 37,1 & 7,2 & 13,4 & 68 & 35,6 \\
\hline $\mathrm{N}_{40} \mathrm{P}_{40} \mathrm{~K}_{40}-$ фон & 7,6 & 16,2 & 72 & 37,5 & 8,2 & 14,4 & 71 & 36,7 \\
\hline Фон $+\mathrm{N}_{30}$ по МТГ & 10,1 & 18,4 & 72 & 38,5 & 10,0 & 18,0 & 69 & 39,1 \\
\hline Фон + N60 по МТГ & 10,9 & 19,5 & 77 & 39,3 & 10,6 & 21,1 & 72 & 39,6 \\
\hline Фон $+\mathrm{N}_{90}$ по МТГ & 11,4 & 22,1 & 78 & 40,0 & 11,6 & 23,4 & 76 & 40,8 \\
\hline
\end{tabular}


норм мінеральних добрив свідчать, що ії̈ зернова продуктивність великою мірою залежала від кількості внесеного азоту у вигляді підживлення ранньою весною по мерзлоталому грунту. Так, якщо у сорту Гурт, який вирощували по чорному пару, урожайність від внесення різних доз азоту ранньою весною по мерзлоталому грунту збільшувалась порівняно з контролем від 0,38 до 0,96 т/га, або від 8,1 до $20,4 \%$, то за сівби озимини після гірчиці, соняшника та пшениці озимої приріст урожаю залежно від внесення азотних добрив варіював у межах 0,39-1,15 т/га, або 10,1-29,7 \%, 0,48-1,17 т/га, або 20,048,7 \% та 0,38-1,23 т/га, або 19,3-62,4 \% відповідно попередникам.

Оцінюючи якісні показники зерна пшениці озимої слід відзначити, що у всіх варіантах досліду в ньому відмічався низький вміст білка - 6,6-12,0 \% (див. табл. 2). За вмістом клейковини та іiі якістю зерно відповідало третьому та четвертому класам.

Разом 3 тим одержані експериментальні дані вказують на те, що якість зерна пшениці озимої за період проведення дослідження суттєво залежала від попередників і азотного підживлення посівів. В зерні сортів Гурт і Антонівка найвищий вміст білка $(12,0 \%)$ i клейковини (відповідно 25,9 і 28,9 \%) одержано на ділянках по чорному пару на фоні передпосівного внесення $\mathrm{N}_{40} \mathrm{P}_{40} \mathrm{~K}_{40} 3$ наступним підживленням посівів азотом $\left(\mathrm{N}_{90}\right)$ по мерзлоталому грунту. За таких умов формувалось зерно третього класу якості. Зі зменшенням дози азотних мінеральних добрив до 30 кг/га д. р. вміст білка в зерні знижувався відповідно сортам до 11,5 та $11,1 \%$, а кількість клейковини - до 24,1 і $23,4 \%$. У ва-

\section{Використана література}

1. Наукові основи агропромислового виробництва в зоні Степу України: зернові культури. Технологї вирошування сільськогосподарських культур. Зернові культури / під ред. М. В. Зубця (голова ред. кол.). Київ: Аграр. наука, 2004. С. 226-284.

2. Система ведення сільського господарства Дніпропетровської області / Головне управління сіл. госп-ва і продовольства облдержадміністрації; Центр наукового забезпечення АПВ Дніпропетровської обл. Дніпропетровськ, 2005. 432 с.

3. Рослинництво 3 основами програмування врожаю / О. Г. Жатов та ін.; за ред. О. Г. Жатова. Київ: Урожай, 1995. 256 с. ріантах без підживлення значення цих показників були найменшими і становили 9,2 і 9,0 та 19,2 і 19,6 \% відповідно.

Залежно від попередника сорти пшениці озимої Антонівка та Гурт формували зерно, яке відповідало третьому класу якості: по чорному пару за умови внесення в передпосівну культивацію $\mathrm{N}_{40} \mathrm{P}_{40} \mathrm{~K}_{40} 3$ наступним підживленням посівів азотом у дозі $\mathrm{N}_{30}$, $\mathrm{N}_{60}$ та $\mathrm{N}_{90}$ по мерзлоталому грунту; після гірчиці $i$ соняшника на фоні передпосівного внесення $\mathrm{N}_{40} \mathrm{P}_{40} \mathrm{~K}_{40} 3$ подальшим підживленням рослин азотом у дозі $\mathrm{N}_{60}$ та $\mathrm{N}_{90}$ по мерзлоталому грунту; після пшениці озимої на фоні передпосівного внесення $\mathrm{N}_{40} \mathrm{P}_{40} \mathrm{~K}_{40} 3$ наступним підживленням посівів азотом по мерзлоталому грунту у кількості 90 кг/га д. р.

Висновки. Як з'ясувалось у ході дослідження, за рахунок азотного підживлення посівів пшениці озимої вміст білка і клейковини в зерні збільшувався, що позитивно позначилось на його крупності. Крім цього, на масу зернівок великою мірою впливали попередники. Так, маса 1000 насінин сорту Антонівка залежно від норм мінеральних добрив і попередників становила: за вирощування пшениці озимої по чорному пару $37,1-43,3$ г, після гірчиці - 36,2-42,6, соняшника - 37,6-41,1, пшениці озимої - 37,140,0 г. У сорту Гурт відповідно попередниникам вона дорівнювала 37,9-43,6 г, 37,743,9; 35,6-40,8; 37,3-41,6 г. Отже, за результатами проведеного дослідження в умовах південного Степу України виявлені кращі попередники і встановлені оптимальні системи мінерального живлення рослин, за рахунок яких можна одержати високу урожайність та якість зерна пшениці озимої.

4. Ремесло В. Н., Сайко В. Ф. Сортовая агротехника пшеницы. Киев: Урожай, 1981. 200 с.

5. Колючий В. Т., Блохін М. І. Якість зерна пшениці. Селекція, насінництво і технології вирощування зернових колосових культур у Лісостепу України. Київ: Аграр. наука, 2007. С. 258-324.

6. Солодушко М. М. Продуктивність озимих зернових колосових культур залежно від попередників та строків сівби в зоні Степу. Бюл. Iн-ту сіл. госnва степ. зони НААН Украӥни. 2015. № 8. С. 9-14.

7. Жемела Г. П., Кулик М. І. Вплив доз мінеральних добрив і способів їх внесення на урожайність та якість зерна озимої пшениці. Наук. пр. Полтав. держ. аграр. академії. 2005. Т. 4 (23). С. 124-127.

8. Солодушко М. М., Гасанова I. І., Прядко Ю. М., 
Носенко Ю. М. Урожайність і якість зерна пшениці і тритикале озимих залежно від попередників та строків сівби. Бюл. Ін-ту сіл. госn-ва cтеп. зони НААН Украӥни. 2016. № 11. С. 35-39.

9. Доспехов Б. А. Методика полевого опыта (с основами статистической обработки результатов исследований). 5-е изд., доп. и перераб. Москва: Агропромиздат, 1985. $352 \mathrm{c.}$

10. Методические рекомендации по проведению полевых опытов с зерновыми, зернобобовыми и кормовыми культурами / под ред. В. С. Цикова, Г. Р. Пикуша. Днепропетровск, 1983. 46 с.

\section{References}

1. Zubets, M. V.(Ed.). (2004). Naukovi osnovy agropromuslovogo vyrabnytsva v zoni Stepu Ukraine: zernovi kultury [Scientific bases of agro-industrial production in the steppe of Ukraine: grain crops] Technology of growing crops. Crops cultures. Kiev: Agrar. science. 226-284. [in Ukrainian]

2. Sistema vedeniya silskogo gospodarstva Dnipropetrovskoy oblasti [The system of agricultural management of the Dnipropetrovsky region]. (2005). Dnipropetrovsk: N. p. [in Ukrainian]

3. Zhatov, O. G. et al. (1995). Roslunuchvo z osnovamu programuvannia vrozhay [Crop production with the basics of programming the harvest]. O. G. Zhatov (Ed.). Kiev: Harvest. [in Ukrainian]

4. Remislo, V. N., Saiko, V. F.(1981). Sortovaia agrotehnika pshenitsy [Variety agrotechnics of wheat] Kiev: Vintage. [in Russian]

5. Colouchiy, V. T., Blohin, M. I. (2007). Yakist zerna pshenichi [The quality of wheat grain] Selection, seed production and technologies of grain cereal cultivation in the forest-steppe of Ukraine. Kiev: Agrar. science. 258-324. [in Ukrainian]

6. Solodushko, M. M. (2015). Productivity of winter wheat cereal crops depending on predecessors and timing of sowing in the zone of the Steppe. Bulletin Institute zernovogo gospodarstva UAAN [Bulletin of Institute of grain farming of the UAAS], 8, 9-14. [in Ukrainian]

7. Zhemela, G. P., Kulik, M. I.(2005). The influence of doses of mineral fertilizers and methods of their introduction on yield and quality of grain of winter wheat. Naukovi pratsi Poltavskoyi derzhavnoi agrarnoiakademii [Science Poltava agrar academy], 4 (23), 124-127. [in Ukrainian]

8. Solodushko, M. M., Gasanova, I. I., Pryadko, Y. M., Nosenko, Y. M. (2016). Productivity and quality of grain of wheat and triticale of winter depending on predecessors and timing of sowing. Bulletin Institute zernovogo gospodarstva UAAN [Bulletin of Institute of grain farming of the UAAS], 11, 35-39. [in Ukrainian]

9. Dospekhov, B. A. Metodika polevogo opyta s osnovami statisticheskoy obrabotki rezul'tatov isledovaniy [Methodology of field experience with the basics of statistical processing of research results] $\left(5^{\text {th }}\right.$ ed. rev.). Moscow: Ahropromizdat. [in Russin]

10. Tsikov, G. S., Pikush, G. R. (1983). Metodicheskie rekomendacii po provedeniyu polevyh opytov s zernovymi, zernobobovymi I kormovymi kulturami [Methodical recommendations for conducting field experiments with grain, leguminous and fodder crops]. Dnipropetrovsk: N. p. [in Russian]

\section{УДК 633.11}

Усова Н. М. ${ }^{1}$, Солодушко М. М. ${ }^{2}$, Романенко О. Л. ${ }^{3}$ Влияние предиественников и минерального питания на урожайность и качество зерна озимой пшеницы. Зерновые культуры. 2018. T. 2. № 2. C. 281-286.

${ }^{1}$ Институт масличных культур НААН, ул. Институтская, 1, пгт. Солнечное, Запорожский район, Запорожская область, 70417, Украина

${ }^{2}$ Государственное учреждение Институт зерновых культур НААН, ул. Владимира Вернадского, 14, 2. Днепр, 49027, Украина

3 Запорожский филиал Государственного учреждения «Институт охраны почв Украины», ул. Опытная станиия, 94, г. Запорожье, 69031, Украина

Освещчены результаты исследования по изучению влияния предшественников и минерального питания на урожайность различных сортов озимой пшеницьв в условиях южной Степи Украиныл. Определены лучшие предшественники и установлены оптимальные системы минерального питания растений, которые обеспечивают высокие показатели урожайности и качества зерна.

На основании данных исследования установлено, что высокую урожайность сорта Антоновка $(5,77 \mathrm{~m} / 2 a)$ и Гурт $(5,67 \mathrm{~m} / 2 a)$ сформировали по черному пару на фоне предпосевного внесения $N_{40} P_{40} K_{40}$ с последующей подкормкой посевов азотом $\left(N_{90}\right)$ ранней весной по мерзлоталой почве. В целом сорта озимой пшениць в зависимости от предшественников реагировали в направлении от лучших к худшим - уменьшением урожайности. В условиях 2015-2017 г2. лучшим непаровым предшественником в опыте для озимой пшеницы была горчица, худиим - озимая пшеницุа.

Установлено, что за счет азотной подкормки посевов озимой пшеницы, содержание белка и клейковины в зерне увеличивалось.

Ключевые слова: озимая пиеница, урожайность, предшественники, минеральные удобрения, качество зерна, белок, клейковина, масса 1000 зерен. 
UDC 633.11

Usova N. N. ${ }^{1}$, Solodushko M. M. ${ }^{2}$, Romanenko O. L. ${ }^{2}$ Influence of predecessors and mineral nutrition on crop yield and grain quality of winter wheat. Grain Crops. 2018. 2 (2). 281-286.

${ }^{1}$ Institute of Oil crops of Ukraine, 1 Institutskaya Str., Zaporozhye district, Zaporozhye region, 70417, Ukraine

${ }^{2}$ SE Institute of Grain Crops of National Academy of Agrarian Sciences, 14 Volodymyr Vernadskyi Str., Dnipro, 49027, Ukraine

${ }^{3}$ Zaporizhzhya Branch of SE «Soils Protection Institute of Ukraine», 94 Doslidna stansia Str., Zaporizhzhya, 69031, Ukraine

One of the important factors in controlling the nutrition of plants, and therefore, increasing yields and improving the quality of winter wheat grain are precursors and fertilizers. Only by providing a sufficient amount of nutrients in a plant during a vegetation can yield a weighty harvest with good technological properties of the grain. Therefore, when developing wheat cultivation technologies, it is necessary to pay special attention to the fertilizer system of cultivated plants.

Field experiments were carried out in 2015-2017 in the crop rotation of the grain crop agronomy laboratory at the Institute of Oilseeds of the National Academy of Sciences of Ukraine. Sowed such varieties of soft winter wheat as Antonovka and Gurt. Sivuba was held on September 25. The predecessors are black pairs, mustard, sunflower, winter wheat. Mineral fertilizers were introduced according to the experimental scheme: without fertilizers; $\mathrm{N}_{40} \mathrm{P}_{40} \mathrm{~K}_{40}$ - background (for pre-sowing cultivation); background $+\mathrm{N} 30$ on frozen ground; background $+\mathrm{N}_{60}$ on frozen ground; background $+\mathrm{N}_{90}$ on permafrost soil. Plant protection measures - taking into account the economic threshold of harm.

Based on the data of the study, it was found that the Antonovka (5.77 t/ha) and Gurt (5.67 t/ha) varieties were produced in black pairs on the background of precipitated introduction of N40P40K40 with subsequent nitrogen fertilization $\left(\mathrm{N}_{90}\right)$ in the early spring on frozen ground In general, wheat varieties of winter replacing predecessors reacted in the direction of the best to the worst - by reducing yields.

Thus, according to the precursor, the black pairs in the variant without fertilizers yielded theAntonovka variety was $4.74 \mathrm{t} / \mathrm{ha}$, whereas after the mustard in similar conditions it decreased by $0.88 \mathrm{t} / \mathrm{ha}$ $(18.6 \%)$, sunflower - by $2,29 \mathrm{t} / \mathrm{ha}(48.3 \%)$, winter wheat $-2.67 \mathrm{t} / \mathrm{ha}(56.3 \%)$. Reduced yields of the varieties of the Group when cultivated after the listed predecessors in comparison with black steam was 17.8, 49.0 and $58.2 \%$, respectively. The same trend was also observed in other variants of the experiment. That is, when growing winter wheat after non-precursors, its productivity significantly changed depending on the predecessor.

It should be noted that for the conditions of the southern Steppe of Ukraine, the blackest couples are the most reliable precursor for winter. In the conditions of 2015-2017, the best non-precursor precursor, among the researchers, was winter wheat for mustard, the worst - winter wheat.

The results of harvesting winter wheat cultivation on the background of introducing various norms of mineral nutrition indicate that its grain productivity to a large extent depends on the amount of introduced nitrogen in the form of nutrition in the early spring on frozen ground.

As it turned out in the course of the study, due to the nitrogen fertilizer of winter wheat crops, the content of protein and gluten increased, which positively affected its size. In addition, the weight of grains was largely influenced by predecessors. Thus, the weight of 1000 seeds of the Antonovka variety depending on the dose of mineral nutrition and its predecessors was: for the cultivation of winter wheat in a black steam $-37.1-43.3 \mathrm{~g}$, after mustard - 36.2-42.6, sunflower - 37.6-41.1, winter wheat $-37.1-40.0 \mathrm{~g}$. In the Variety Group, according to its predecessors, it was $37.9-43.6 \mathrm{~g}, 37.7-43.9 ; 35.6-40.8 ; 37.3-41.6 \mathrm{~g}$.

Consequently, according to the results of the conducted research in the conditions of the southern Steppe of Ukraine, the best predecessors were found and optimal mineral nutrition systems were installed, due to which high grain yield and quality of winter wheat can be obtained.

Key words: winter wheat, yield, precursors, mineral fertilizers, grain quality, protein, gluten, weight of 1000 grains. 